\title{
MENUJU KESEIMBANGAN BARU ANTARA KESELAMATAN KONDISI EKONOMI DAN KESELAMATAN KONDISI KESEHATAN DI TENGAH PANDEMI (COVID 19) KABUPATEN KUTAI KARTANEGARA (Sebuah Perspektif Akademik)
}

\author{
Oleh : Iskandar \\ Dosen Fakultas Ekonomi dan Bisnis \\ Universitas Kutai Kartanegara
}

\begin{abstract}
:
The management of the COVID-19 pandemic in this area is racing towards a balance between the safety of economic conditions and overall health conditions. This management is expected to prioritize saving lives as much as possible in the short term with the disaster relief paradigm, and then economic recovery and prosperity in the medium and long term. Social safety net during disaster relief is needed not only for the poor but also vulnerable middle-class people. A distribution policy mix is needed to accelerate the process and the quality of disbursements.

Policies for Micro, Small and Medium Enterprises and banks are directed at reducing liquidity. In the mid-term recovery process, the focus of the policy is on reducing pressure from the supply side. Ensuring the business world can operate immediately, maintaining the sustainability of the logistics sector and encouraging industrial independence.
\end{abstract}

\section{Keywords : safety of economic conditions and overall health conditions.}

\section{PENDAHULUAN}

Suatu assessment dengan skenario terburuk menyatakan Indonesia akan mengalami perlambatan ekonomi hingga minus 0.4 persen, yang juga akan berdampak pada kondisi ekonomi kabupaten Kutai Kartanegara. Proyeksi pertumbuhan oleh berbagai lembaga internasional (seperti IMF, ADB dan World Bank)) tersebut menunjukkan divergensi di tengah ketidakpastian ekonomi akibat pandemi Covid-19. Di samping itu, resesi atau perlambatan ekonomi juga terjadi secara luas, dimana mitra dagang utama Indonesia pun akan mengalami kontraksi (Tim Ahli UI,2020:6).

Hal ini sejalan dengan kondisi ekono-mi dan sosial kabupaten Kutai Kartanegara yang sedang berusaha memanajemeni dampak penyebaran virus corona.

Sebagaimana diketahui bahwa hampir semua daerah di negeri ini masih fokus menangani pandemi Corona Virus Disease 2019 (COVID-19) yang pada akhirnya mengganggu kepercayaan investor, sektor pariwisata/travel, supply chain dan pasar keuangan. Prospek pelemahan ekonomi daerah dan nasional tersebut diperparah lagi dengan kecenderungan pelemahan harga minyak mentah global, yang berarti bahwa penerimaan daerah kabupaten Kutai Kartanegara (Kukar) akan semakin berkurang, karena selama ini struktur perekonomian kabupaten Kutai Kartanegara masih didominasi oleh sektor pertambangan minyak dan gas bumi.

Dari sisi fiskal, penerimaan akan mengalami risiko revisi yang diprediksi akan cukup signifikan. Ketidaksepakatan negaranegara OPEC mengenai pengurangan produksi minyak berdampak terhadap rendahnya komoditas minyak. Proyeksi akan lemahnya harga komoditas ke depan dapat menyebabkan eksportir komoditas mengala-mi tekanan dari sisi pembiayaan dan aktivitas usahanya. Porsi pendapatan negara yang masih cukup didominasi dari sektor migas sekiranya perlu mendapatkan perhatian utama dari Pemerintah terkait proyeksi penurunan harga komoditas ini. Dengan kata lain penerimaan daerah (APBD) 
kab.Kukar hingga saat ini masih didominasi dari dana bagi hasil (DBH) minyak dan gas bumi.

Fakta situasi saat ini bahwa, pandemi virus corona atau Covid-19 telah merusak hingga ke level konsumsi masyarakat di bawah. Di mana untuk mengendalikan penyebaran virus ini, salah satu cara terbaik yang dilakukan adalah masyarakat tinggal di rumah dan mengurangi aktivitas di luar. Sekolah diliburkan, karyawan sebagian besar harus bekerja di rumah, tempat wisata dan hiburan terpaksa ditutup. Dengan berhenti-nya aktifitas tersebut tentu warung-warung kecil, pasar-pasar tradisional yang berada di sekitar lokasi akan berhenti.

Setelah mengamati dan mengkaji publickasi perkembangan penanganan pandemi COVID-19 selama ini maka ada beberapa hal yang menurut hemat saya perlu mendapat perhatian sebagai landasan dalam menyusun kebijakan dan strategi untuk menuju keseimbangan antara keselamatan kondisi ekonomi dan keselamatan kondisi kesehatan yaitu :

1. Data perkembangan penyebaran pandemi dalam hal ini OTG, ODP, PDP dan Positif COVID-19.

2. Data perkembangan masyarakat yang terdampak pandemi ini (terutama masyarakat miskin).

Dengan demikian strategi untuk menuju keseimbangan antara keselamatan kondisi ekonomi dan keselamatan kondisi kesehatan akibat pandemi corona virus disease 2019 (COVID 19) yang dilakukan harus berbasis data-data. Hal ini diharapkan agar solusi yang ditempuh tepat sasaran dan efektif.

\section{REVIEW KEBIJAKAN}

\section{Review Kebijakan Menekan Sebaran Infeksi}

Sebagaimana kondisi di tingkat global, kebijakan surpresi menjadi pilihan utama melalui upaya menekan sebaran infeksi dengan penerapan jaga jarak yang sangat ketat skala besar, hingga penerapan karantina wilayah. Para peneliti dan ahli epidemiologi sangat menekankan penerapan surpresi karena dua resiko besar jika upaya ini tidak dilakukan. Pertama adalah, jangka waktu untuk ditemukannya vaksin masih cukup lama.
Kedua, tidak semua negara memiliki sistem layanan kesehatan yang kuat. Sebaliknya, kebijakan mitigasi dalam menekan sebaran infeksi tanpa melakukan upaya keras untuk memutus rantai penyebaran, berimplikasi pada jumlah kematian yang cukup tinggi secara akumulatif. Dalam konteks ekonomi, ini merupakan hilangnya human capital -investasi yang cukup mahal dan perlu waktu lama. Rendahnya kasus terkonfirmasi di negaranegara dengan kemampuan tes atau deteksi COVID-19 yang rendah, termasuk Indonesia menjadi krusial perlu untuk direspon dengan cepat. Rendahnya kemampuan tes berimplikasi pada dua hal. Pertama jumlah kasus terkonfirmasi seolah-olah rendah. Kedua, tingkat kesadaran publik untuk melakukan pembatasan sosial menjadi lebih rendah. Selain itu, secara praktis, tes yang rendah juga menyulitkan tenaga kesehatan untuk melakukan antisipasi dan perencanaan penanganan kasus positif dengan baik dan efisien. Peningkatan kapasitas tes, khususnya PCR (Polymerase Chain Reaction) sangat mendesak dan penting untuk dilakukan (Tim Ahli UI,2020:8-9).

Pemerintah kabupaten Kutai Kartanegara sebagaimana telah diuraikan sebelumnya memiliki tiga tantangan besar dalam menekan sebaran infeksi yaitu :

1. Sektor kesehatan yang masih perlu dukungan sumber daya,

2. Kapasitas fiskal yang terbatas, dan

3. Disiplin masyarakat yang rendah.

Keberhasilan menekan sebaran wabah akan bepengaruh terhadap jumlah korban jiwa, dan kemampuan ini juga ditentukan oleh kapasitas sektor kesehatan, baik tenaga maupun fasilitas kesehatan. Penguasaan teknologi untuk melakukan tes, di daerah ini juga masih relatif terbatas.

Kemampuan anggaran pemerintah pusat dan daerah terbatas untuk memperbesar kemampuan sektor kesehatan. Di samping itu, kemampuan serap sektor kesehatan untuk alokasi anggaran yang lebih besar pun juga terbatas. Untuk menekan sebaran infeksi, diperlukan disiplin masyarakat yang tinggi. Namun dengan belum terbangunnya kesadaran bahaya infeksi COVID-19, harapan untuk kedisiplinan ini akan sulit. 
Data-data kondlis membaiknya aspek kesehatan nampak dari kurva dan gambar berikut ini:;
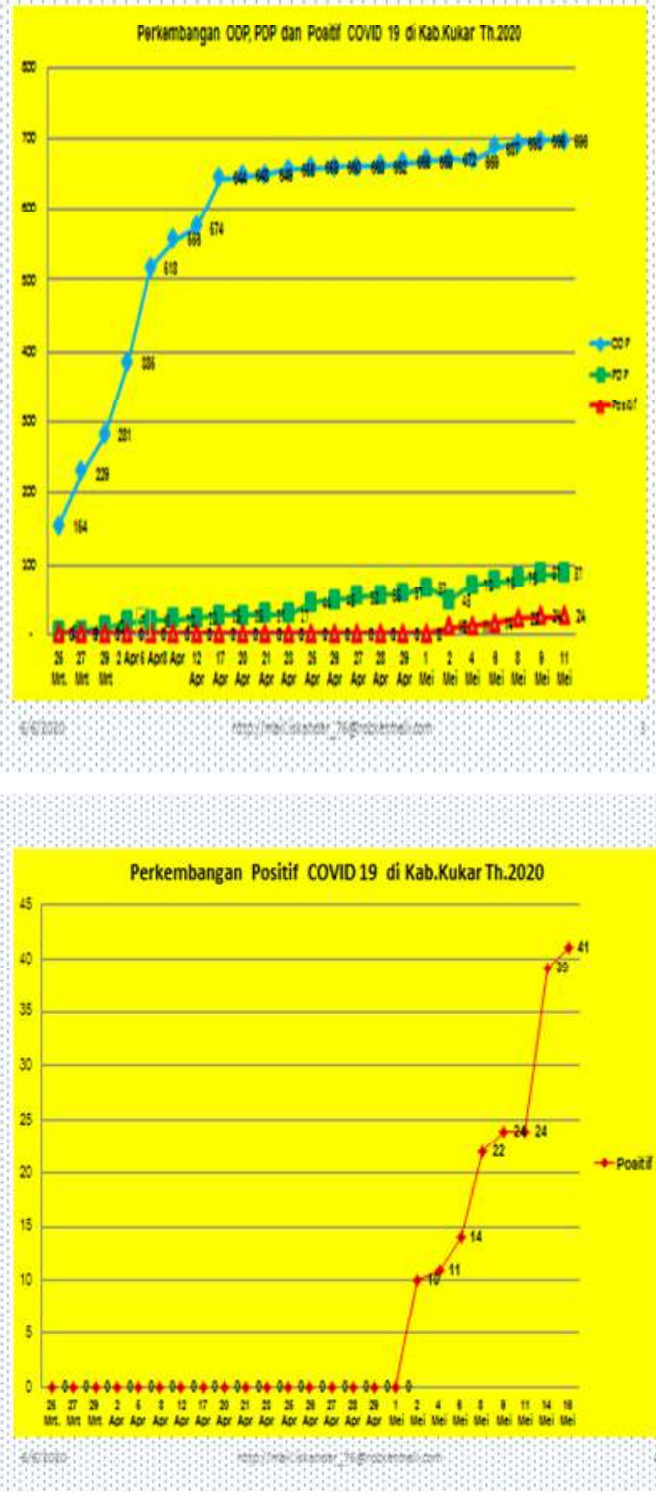

Persebaran ODP, POP dan Positif COMD 19 di Kab.Kukar Th. 2020 Per Kecamatan s/d tgl. 11 Mei 2020 noce $=p 0 P$ mposeti

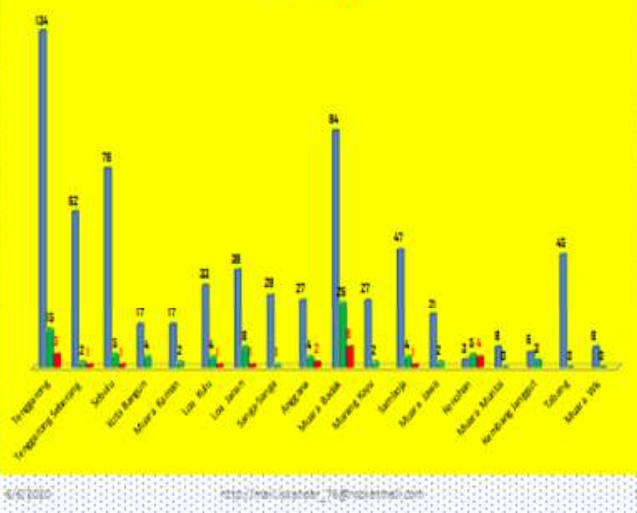

\section{Kapan Covid akan berakhir?}

\begin{tabular}{|c|c|c|c|}
\hline & Lembraza & Catupan & Whatu athir pandeni \\
\hline 1 & SITD, Singopur & Indonesia & 20luni 2020 \\
\hline 2 & McKinseys Company & Dunia & Kuartal 4,2020 (Oktober,2020) \\
\hline 3 & P2MSm ITB & Indonesia & Akhir Mei atau awal luni 2020 \\
\hline 4 & BIN & & Puncak tangezl 2-22 Mei 2020 \\
\hline 5 & Sutanto Sastraredia (Matematib, UNS) & & Penurunan teriadi paca tanezal 11 Juni \\
\hline 6 & PMPAUGMI & & $29 \mathrm{Me} 2020$ \\
\hline 1 & Hasbulah Thabrany, FKM UI & & Bulan Nei 2020 \\
\hline 8 & Badan Inteljen Nezara & & Achir Jull 2020 \\
\hline
\end{tabular}

\section{Review Kebijakan Sosial dan Ekonomi}

Kebijakan sosial dan ekonomi dalam hal ini dilandasi asumsi untuk mencari keseimbangan antara keselamatan dan kesehatan masyarakat (kondisi sosial) dengan kondisi ekonomi, tanpa memprio-ritaskan antara satu dengan lainnya. Perekonomian yang terdampak, akibat pandemi COVID-19 ini akan berakibat lebih jauh terhadap keberlangsungan kehidupan masyarakat. Namun demikian, mengingat korban jiwa yang terus bertambah, maka perlu kiranya upaya dalam usaha penyelamatan jiwa dan kesehatan untuk dikedepankan khususnya dalam jangka pendek. Dengan demikian, paket kebijakan disusun selaras dengan containment strategy (penahanan/pencegahan) yang dipilih sehing-ga dapat meminimalkan korban, stimulus diberikan dengan kerangka pikir ;

(i) Disaster relief dalam jangka pendek, relief dalam hal ini artinya memasti-kan program kesehatan tetap berjalan dengan terpenuhinya persyaratan minimal dan,

(ii) Menghindari resesi di jangka menengah. Kebijakan jangka pendek yang beriorientasi pada disaster relief process dengan titik tekan pada stimulus sektor kesehatan dan bantuan sosial kesejahteraan bagi rakyat yang terdampak. Hal ini telah dilakukan dengan cara, antara lain: meningkatkan jumlah tempat tidur, jumlah staf medis, ventilators, alat pelindung diri (APD), peningkatan jumlah dan skala tes 
COVID-19, memberikan insentif untuk para medis telah dilakukan di atas segala-galanya. Upaya-upaya disaster relief ini hingga saat ini telah cukup berhasil dijalankan di daerah ini. Kondisi ini dapat di lihat dari data-data mengenai perkembangan OTG, ODP, PDP dan Positif terinfeksi COVID 19 yang semakin menurun dari waktu ke waktu. Oleh karena itu tanpa memprioritaskan sektor kesehatan, kebijakan ekonomi tidak akan berarti terlalu banyak. Dengan demikian upaya utama untuk menekan kerusakan ekonomi dari krisis kesehatan COVID-19 bertumpu pada upaya menekan penyebaran infeksi dengan konsekuensi sosial dan ekonomi besar dan berat bagi masyarakat.

Upaya menekan penyebaran infeksi COVID-19 ini bentuknya beragam, mulai dari pembatasan-pembatasan sosial, sampai surpresi dalam bentuk karantina wilayah secara total. Namun demikian dampak dari pembatasanpembatasan sosial ini cukup berat dirasakan oleh masyarakat.

Dari sisi fiskal, penerimaan daerah menga-lami risiko revisi yang diprediksi cukup signifikan. Sumber-sumber penerimaan utama daerah berupa hasil minyak dan gas bumi yang semakin menurun berdampak pada berkurangnya APBD. Dengan demikian dari sisi ekonomi dan keuangan, pemerintah kabupaten Kutai Kartanegara segera melakukan berbagai emergency responses dalam rangka menangani dampak yang ditimbulkan dalam jangka pendek, melalui 3 (tiga) hal utama sebagai berikut:

1) Mengurangi dampak ekonomi yang dihadapi oleh masyarakat karena Covid19 ,

2) Menjaga perekonomian untuk tetap berjalan, dan

3) Mengupayakan agar perekonomian bisa bergerak cepat ketika krisis ini telah usai.

Ada dua pihak yang perlu diperhatikan oleh Pemerintah kabupaten Kutai Kartanegara.

- Pertama adalah pekerja atau rumah tangga dan

- Kedua adalah perusahaan atau industri.

Dalam rangka mengurangi dampak ekonomi yang dihadapi oleh masyarakat, pemerintah kabupaten Kutai Kartanegara lebih fokus kepada masyarakat yang akan terkena dampak paling besar, seperti ;

a. Pekerja kerah biru,

b. Pekerja dengan upah harian atau upah sangat rendah,

c. Pekerja usia muda,

d. Pekerja di sektor informal,

e. Para pengangguran, para pencari kerja, dan

f. Orang-orang yang bekerja sendiri (selfemployed)

Pekerja-pekerja ini membutuhkan dukungan finansial karena ketidak-pastian ekonomi yang mereka hadapi. Lebih dari itu, pekerja sektor informal ini merupakan mayoritas dari total pekerja di Indonesia dan yang akan merasakan dampak paling besar.

Menyebarnya pandemi dan diterapkan-nya pembatasan-pembatasan sosial di beberapa wilayah, maka banyak golongan masyarakat yang mengalami penurunan pendapatan dan bahkan harus kehilangan mata pencahariannya, khususnya yang bekerja di sektor informal. Dampak dari dilakukan pembatasanpembatasan, ter-sebut pada gilirannya berpotensi terjadinya pertam-bahan jumlah penduduk miskin. Ini artinya, beban pemerintah daerah untuk mengatasi persoalan kemiskinan, baik melalui subsidi, bantuan sosial dan lainnya, menjadi semakin besar. Apalagi, jika bantuan sosial yang diberikan pemerintah tidak mencukupi atau datang terlambat, golongan rentan dan hampir miskin akan semakin banyak yang jatuh ke bawah garis kemiskinan. Dampak terburuk dalam hal ini di lihat dari kondisi ekonomi rumah tangga/ keluarga miskin yg.semakin meningkat.

Jika melihat data-data BDT atau data $\mathrm{PKH}$ (di bawah ini) maka dapat dikemuka-kan bahwa masyarakat miskin pada wilayah2 ; Samboja, Anggana, Ma.Kaman, Marang Kayu, inilah yg.menjadi fokus perhatian program penyelamatan, perlindungan dan pemberdayaan dampak pandemi COVID 19 ini. Namun demikian data ini masih harus di update lagi, tetapi fokus pemerintah daerah harus pada wilayah2 yg.banyak penduduk miskinya. Sebab, sebelum terjadi bencana sosial/pandemi ini saja mereka sudah miskin/kesulitan hidup, apalagi pd.situasi saat ini. 


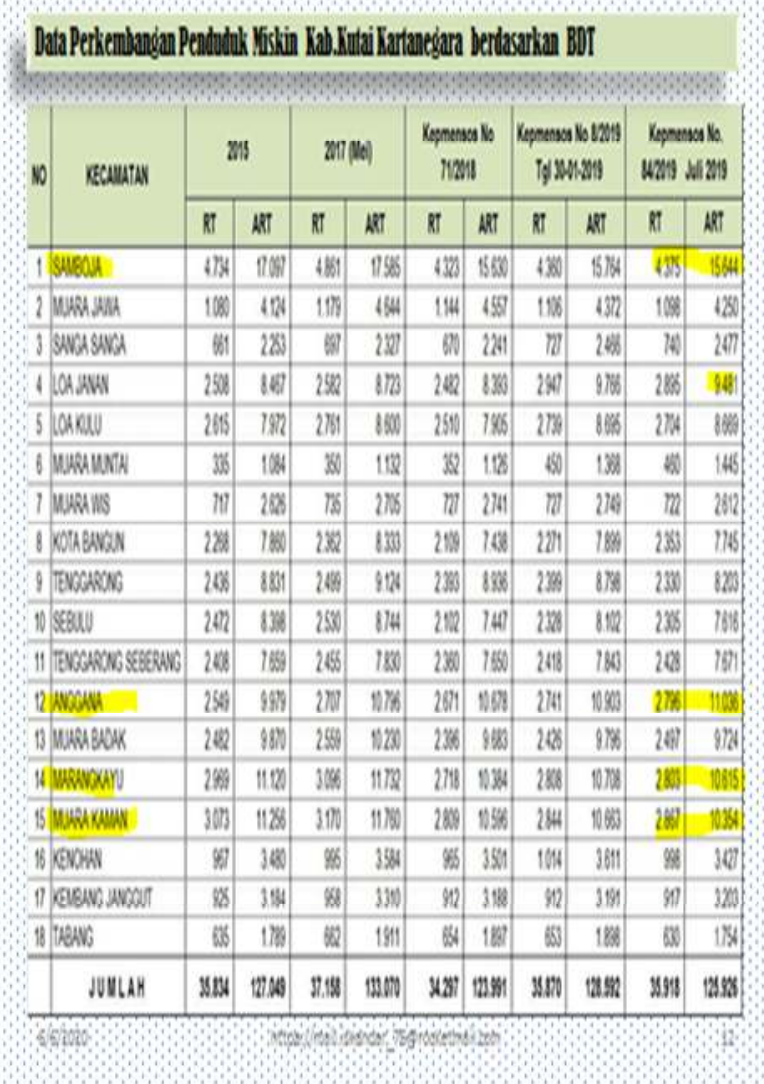

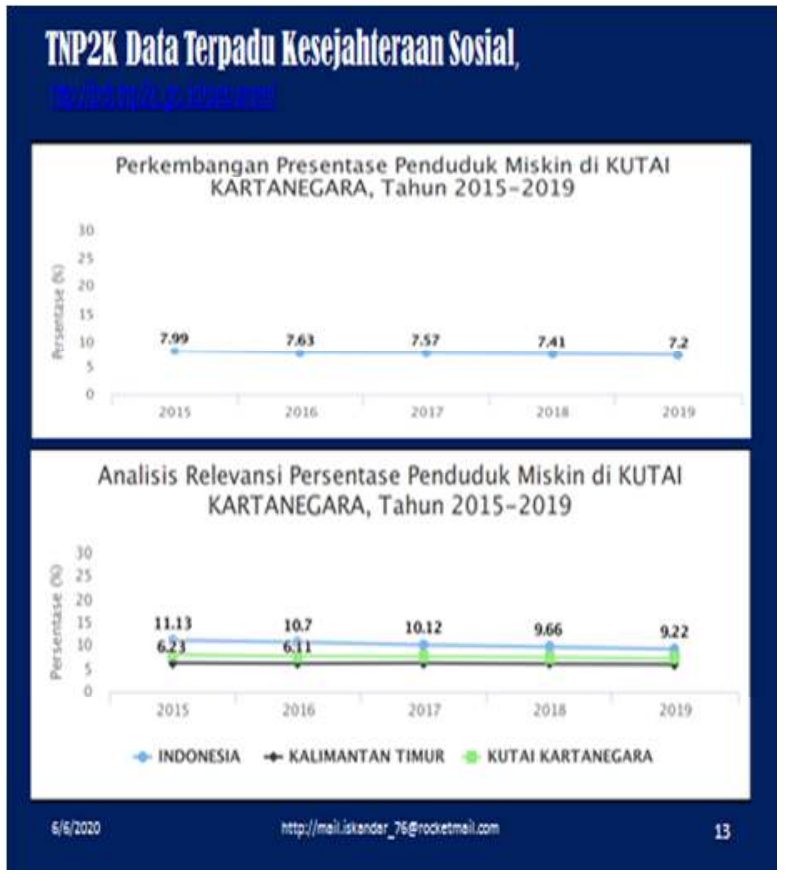

Merujuk pada konsep/indikator dan datadata "makro" yang diperoleh dari BPS baik data tentang persentase penduduk miskin, garis kemiskinan maupun data pengeluran konsumsi penduduk, maka berikut ini dapat disusun simulasi penghitungan peningkatan jumlah penduduk miskin di kab.Kutai Kartanegara.

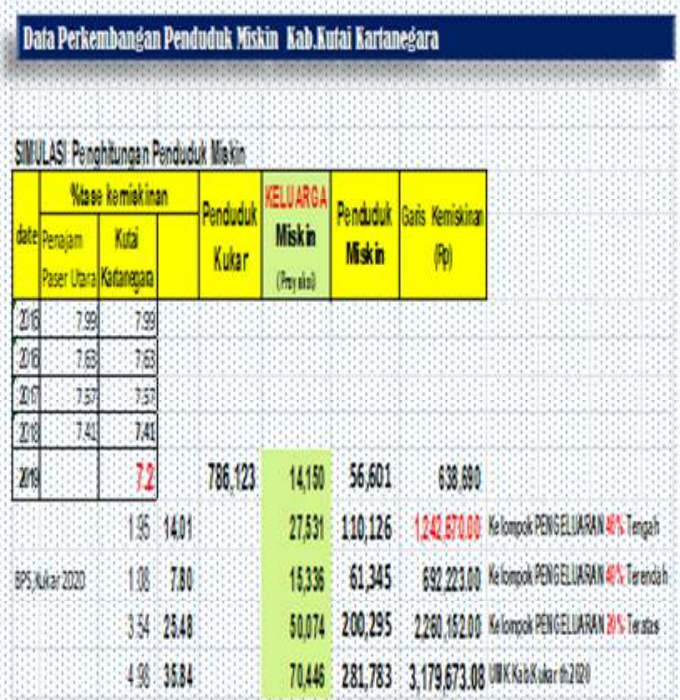

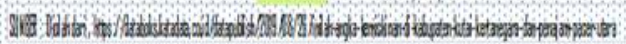

काpo

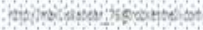

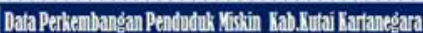

Jika Garis Kemiskinan Kab.Kukar ini disesuaikan dengan nilai pendapatan per kapita per bulan yaitu Rp 638,690 , maka penduduk miskin Kab. Kukar sekitar 8,03 atau63,134 jiwa. (sedikitdiatas data BDT/PKH)

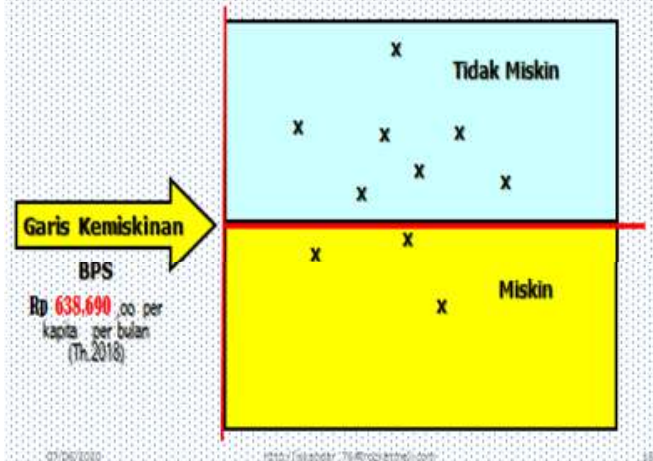

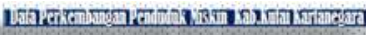

IETAPI jika Garis Kemiskinan Kab.Kukat in disesuaikan dengan nilai UMK th.2020 yatu Rp 3.179,673.08 atau kurang-lebih \& kall lipat dari garis keniskinan BPS 2018 (Rp $(388,690,00)$, naka dapat dipredilsil bahwa tingkat keniskinan th.2020 menjadi $40.15 \%(8,03 \% \times 5)$ atau 315.628 jwa penduduk miskin dari 786,123 Jiwa penduduk Kab.Kukat.

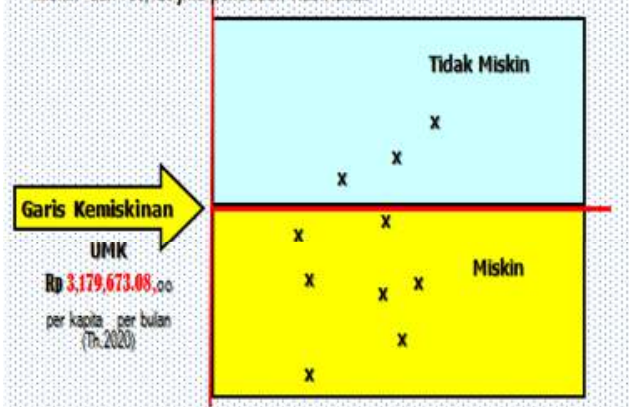

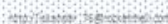


Data hasil simulasi ini yang selanjutnya digunakan untuk membuat skenario peningkatan jumlah penduduk miskin di kab.Kutai Kartanegara di tengah kondisi pandemi COVID 19.

Jika data jumlah ODP, PDP dan Positif COVID 19 di atas disandingkan dengan data jumlah penduduk miskin tersebut nampak bahwa jumlah penduduk miskin yang terdampak pandemi lebih besar dibanding jumlah ODP, PDP dan Positif COVID-19. Fakta ini semakin menyakinkan bahwa strategi kebijakan berikutnya adalah "bagaimana upaya penanganan dampak sosial dan ekonomi, serta upaya pencegahan oleh seluruh masyarakat dengan sungguh-sungguh. Selain itu, hal ini juga menunjuk-kan perlu alokasi anggaran untuk penanganan dampak sosial ekonomi perlu diperbesar, setidaknya proporsional dengan anggaran penanganan kesehatan.

Dengan analasis terhadap garis kemis-kinan dan konsep pengeluaran konsumsi masyarakat tersebut maka dapat diklasifi-kasikan kondisi jumlah penduduk miskin ke dalam 3 (tiga) skenario kondisi sbb.:

1. Skenario Kondisi Berat

2. Skenario Kondisi Lebih Berat

3. Skenario Kondisi Sangat Berat

Skenario berat, jika potensi pertambahan jumlah penduduk miskin mencapai $14.01 \%$ atau sekitar 110.126 jiwa/ 27.532 Keluarga. Skenario lebih berat, jika potensi pertambahan jumlah penduduk miskin mencapai $25,48 \%$ atau sekitar 200.295 jiwa/ 50.074 Keluarga.

Skenario sangat berat, jika potensi pertambahan jumlah penduduk miskin dapat mencapai $25,48 \%$ atau sekitar 281.783 jiwa/ 70.446 Keluarga.

Selanjutnya proyeksi kebutuhan anggaran nampak pada table berikut.

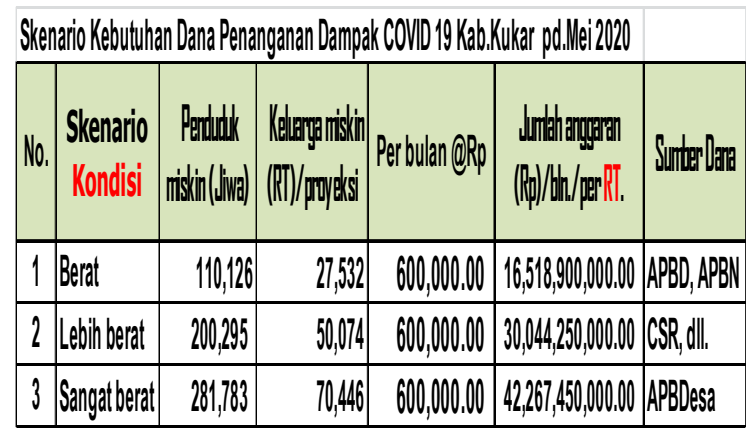

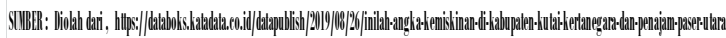

\section{ANALISIS KEBIJAKAN}

\section{Fokus Manajemen Kondisi Pandemi}

Fokus manajemen pandemi Covid-19 dari sisi ekonomi menjadi 2 (dua) periode utama, yaitu :

- Periode pertama merupakan periode jangka pendek dan mendesak dengan berfokus kepada pengurangan penambahan korban jiwa dari Covid-19.

- Periode kedua akan meliputi rencana jangka menengah dan panjang pasca berakhirnya masa-masa kritis pandemi.

Pada periode jangka pendek, manajemen pandemi dapat lebih berfokus kepada emergency response, terutama dalam rangka penyelamatan dengan mengurangi dampak ekonomi jangka pendek yg.dihadapi oleh masyarakat (spt.: UMKM, PKL, dsj.) karena Covid-19. Melakukan realokasi sebagian anggaran belanja modal dan belanja barang di APBD, dan melakukan pembagian beban (burden sharing) antara Pemerintah kabupaten dan pemerintah desa dengan mengalihkan sebagian anggaran Transfer Ke desa (ADD \& Dana Desa), untuk dialokasi-kan menjadi anggaran Bantuan Sosial/ BANSOS daerah setempat.

Penyelamatan melalui mekanisme bansos diperuntukkan bagi pelaku usaha kecil dan menengah yg.masuk kategori usahanya berhenti/ tidak bisa lagi berjualan/berusaha. Para pelaku usaha dalam skema tersebut diupayakan agar masuk sebagai penerima bantuan sosial dari pemerintah.

Periode jangka menengah dan panjang, manajemen pandemi dapat lebih berfokus meminimalkan resesi atau perlambatan pertumbuhan ekonomi melalui :

1. Skema perlindungan (mekanisme ekono-mi) diperuntukkan bagi UMKM yang masih bisa bertahan. Menjaga dan melindungi agar kegiatan ekonomi tetap bisa berjalan pd. saat terjadinya pandemi COVID 19, Skema ini antara lain berupa relaksasi dan restrukturisasi kredit UMKM meliputi :

a. Pembukaan (secara selektif, bertahap dan dengan memperhatikan protocol kesehatan) untuk akses pasar rakyat 
b. Revitalisasi pasar rakyat dan penataan wilayah sebaran keberadaan pedagang kaki lima,

c. Stimulus bantuan modal kerja darurat yang dirancang khusus bagi pelaku UMKM yang merasakan dampak Covid19.

d. Penundaan angsuran dan subsidi bunga bagi para penerima KUR (Kredit Usaha Rakyat), UMi (Kredit Ultramikro), LPDB (lembaga pengelola dana bergulir), hingga penerima bantuan permodalan dari beberapa kementerian.

e. Dan sejenisnya.

2. Skema pemberdayaan yg. berfokus pada mengurangi tekanan dari sisi penawaran dan permintaan (supply \& demand shocks). Memastikan perusahaan/UMKM untuk langsung beroperasi, menjaga kesinambungan sektor logistik, serta mendorong kemandirian industri hasil pertanian, peternakan, perikanan maupun rantai industrinya menjadi kunci. Skema ini antara lain berupa relaksasi :

a. Insentif perpajakan yang berlaku bagi para pelaku UMKM dengan omzet di bawah $\mathrm{Rp}$ 4,8 miliar per tahun (dari pemerintah PUSAT telah menurunkan tarif $\mathrm{PPh}$ final selama enam bulan, pemerintah daerah dapat memediasi-kan). Jika kebijakan dari sisi penawa-ran telah diambil maka focus kebijakan jangka menengah selanjutnya yang dapat diambil oleh pemerintah adalah upaya-upaya pemulihan aggregate demand. Penghapusan pajak seperti PPN dan PPh setelah pandemi akan membantu mendorong permintaan. Selain itu, pemerintah harus memberi stimulus kepada rumah tangga untuk konsumsi barang manufaktur, dan sektor jasa seperti restoran, hotel dan pariwisata serta angkutan dan penerbangan. Perhatian khusus perlu diberikan kepada sector pariwisata dan transportasi yang paling terdampak oleh pandemi ini (LPEM, 2020)

b. Pemerintah daerah/pemkab bertindak sebagai penyangga dalam ekosistem UMKM, dalam hal ini pemkab, BUMN atau BUMD menjadi offtaker (penyerap) bagi hasil produksi para pelaku UMKM baik di bidang pertanian, perikanan, kuliner, sampai di industri rumah tangga.(sisi demand). Sustaianabilitas sektor pangan dan makanan dan minuman jadi adalah kunci dari sustainabilitas perekonomi-an. Sektor pangan mengalami penuru-nan permintaan yang signifikan oleh karena penurunan permintaan dari agen ekonomi berskala besar. Dengan turunnya permintaan, harga akan cenderung turun (telah terjadi untuk kasus daging ayam dan telur) dibawah biaya produksi untuk itu, pemerintah harus mensubsidi biaya input atau melakukan mekanisme harga batas bawah atau masuk ke pasar untuk melakukan pembelian. Sektor pangan juga memerlukan perhatian dengan semakin terbatasnya jumlah yang diperdagangkan dalan perdagangan internasional terutama beras.

c. Akhir dari pemberdayaan adalah kemandirian.

\section{PENUTUP}

Manajemen pandemi COVID-19 di daerah ini berpacu menuju keseimbangan antara keselamatan kondisi ekonomi dan keselama-tan kondisi kesehatan. Manajemen ini diharapkan agar mengede-pankan penyela-matan nyawa sebanyak-banyaknya pada jangka pendek dengan paradigma disaster relief, dan kemudian pemulihan ekonomi dan kesejahteraan dalam jangka menengah dan panjang. Social safety net selama disaster relief diperlukan tidak hanya bagi kelompok miskin tetapi juga masyarakat menengah vulnerable/rentan. Bauran kebija-kan distribusi diperlukan untuk mem-percepat proses dan kualitas disbursement.

Kebijakan untuk UMKM dan perbankan diarahkan untuk meringankan likuiditas. Dalam proses recovery jangka menengah, fokus kebijakan ada pada pengurangan tekanan dari sisi penawaran. Memastikan dunia usaha dapat langsung beroperasi, menjaga kesinambungan sektor logistik dan mendorong kemandirian industri. 


\section{DAFTAR PUSTAKA}

BPS.Kab.Kukar.2020. Kutai Kartanegara Dalam Angka 2020.

BPS.Kab.Kukar.2019.Statistik Daerah Kabupaten Kutai Kartanegara 2019.

BPS.Kab.Kukar.2019.Statistik Kesejahteraan Rakyat Kabupaten Kutai Kartanegara 2019.

Rahma Iryanti,2017. Deputi Menteri Perencanaan Pembangunan Nasional/Deputi Kepala Bappenas, Jakarta, 15 Juni 2017.

Revindo, M. D., Sabrina, S., \& Sowwam, M. (2020). Dampak Pandemi COVID-19 terhadap Pariwisata Indonesia: Tantangan, Outlook dan Respon Kebijakan. LPEM Briefing Note.

Suryahadi, A., Izzati, R.A., \& Suryadarma, D. (2020). The impact of COVID-19 Outbreak on Poverty: An estimation for Indonesia. SMERU Working Paper.

Susamto,Akhmad Akbar dan Muhammad Ishak Razak.2020. Lima Langkah Antisipasi Lonjakan Kemiskinan Akibat Pandemi Covid-19, CORE Indonesia (Center of Reform on Economics).

Tim Ahli Universitas Indonesia, 2020. Policy Brief1,Kebijakan Ekonomi Di Tengah Pandemi Covid-19: Selamatkan Nyawa, Minimalisasi Resesi.

https://databoks.katadata.co.id/datapublish/2019 /08/26/inilah-angka-kemiskinan-dikabupaten-kutai-kertanegara-danpenajam-paser. 